\title{
Lorenz Frølich i Flensborg 1854-1857
}

Af Borge L. Barløse

Et af de indtryk, der ved et besøg på Duborgskolen fæstner sig stærkest hos gæster af den ældre generation, er nok mødet med Lorenz Frølichs billeder: $i$ festsalen Hagbard og Signe og to af de prægtige, farvede sidevinduer, i korridoren de store kartoner, hvoraf vel navnlig "Rolf og hans kæmper« danner et højdepunkt - trods den alt for korte afstand mellem billedflade og beskuer. Mange har jo endnu en klar erindring om, hvordan Frølichs tegninger langt ind $\mathrm{i}$ vort århundrede var afgørende for et slægtleds oplevelse af sagntidens skikkelser og situationer.

Besøgende med et mere fortroligt forhold til grænsebyen vil vide, at Lorenz Frølich har en anden, helt speciel tilknytning til Flensborg, idet han var mester for de to store historiemalerier, der et kort åremål indtil 1864 smykkede appellationsrettens sal: "Valdemar Sejr giver Jyske Lov« og »Frederik 4. hyldes af stænderne på Gottorp«. Om dette værk fik læserne af Sønderjyske Årbøger i 1946 en bred og kyndig orientering ved Erik Bondo Svanes afhandling om stadsbygmester L. Winstrups virksomhed. ${ }^{1}$

Til dette meget fortjenstfulde arbejde slutter sig adskillige andre bidrag, overvejende af rent kunsthistorisk art, fra de senere årtier. De er imidlertid spredt over talrige, vidt forskellige publikationer. ${ }^{2} \mathrm{Da}$ nu ydermere Bondo Svane i sin behandling af emnet snarere har Winstrup som indfaldsvinkel end Frølich, forekommer det mig, at det foreliggende materiale indbyder stærkt til en nærmere betragtning af Frølichs 3årige ophold i Flensborg. At belyse dette mellemspil med dets biografiske og lokalhistoriske aspekter er da formålet med den følgende fremstilling.

Frølich var i 1852, da han fik den store udsmykningsopgave tildelt, nået til et ret afgørende punkt i sin udvikling. 32 år gammel var han stort set færdig med sine studier, havde årelange ophold i Dresden og Rom bag sig og havde senest modtaget nye impulser som elev hos den franske maler Th. Couture. Den første anerkendelse fra hjemlandet 
havde allerede vist sig, idet A. Fabricius til førsteudgaven af sin "Danmarkshistorie for folket« (1854) benyttede et antal pennetegninger af Frølich.

Den næste opbakning udgik fra hans ven og landsmand, L. A. Winstrup, der i sin egenskab af stadsbygmester havde fået overdraget ombygningen af en større ejendom ved hovedgaden i Flensborg til regeringskontorer og sæde for appellationsretten. ${ }^{3}$ Ved forelæggelsen af sit projekt anbefalede Winstrup over for bygherren, Det slesvigske Ministerium i København, at Frølich ("den talentfulde maler Lorenz Frølich, der netop er vendt tilbage til Danmark «) kom i betragtning ved udførelsen af 2 store vægdekorationer til sidevæggene i retslokalet, og han lod samtidig vennen forstå, at en stor chance nu var under opsejling. ${ }^{4}$

Forslaget, der var lige så velmotiveret som det var velment, gik dog ingenlunde glat igennem. Mens kunstneren selv forestillede sig billeder af mytologisk indhold, insisterede ministeren, Carl Moltke, på, at der burde vælges sådanne historiske motiver, at der tillige kunne lægges en politisk betydning $\mathrm{i}$ dem. Som et muligt kompromis tilskyndede Winstrup sin ven til at lave et udkast med Thyra Danebod som den centrale figur. ${ }^{5} \mathrm{Da}$ man i København dannede sig det indtryk, at sagen blev forhalet med den hensigt stadig at holde en mulighed åben for de

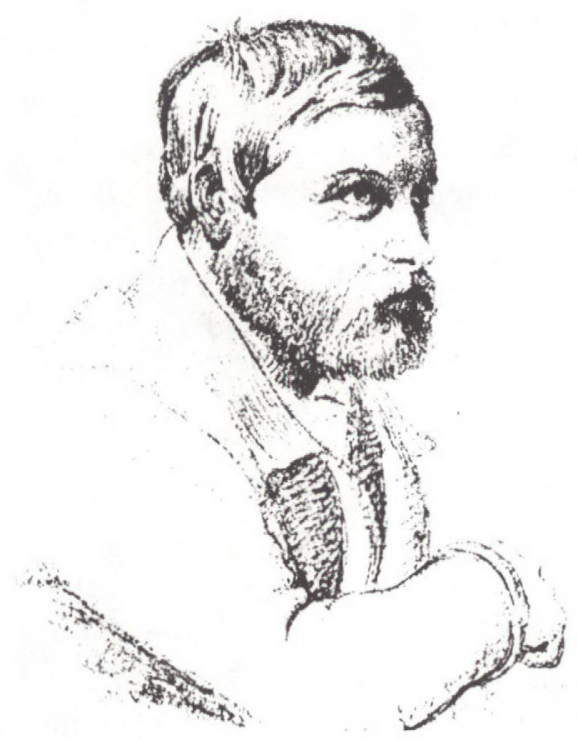

Lorenz Frelich (1820-1908), maler og tegner, er nok mest kendt som skildrer af mytologiske og historiske optrin. Flere af hans arbejder blev til $i$ Flensborg, hvor han boede $i$ drene 1854-57. (Tegning af Vilh.Kyhn, Rom 1851). 


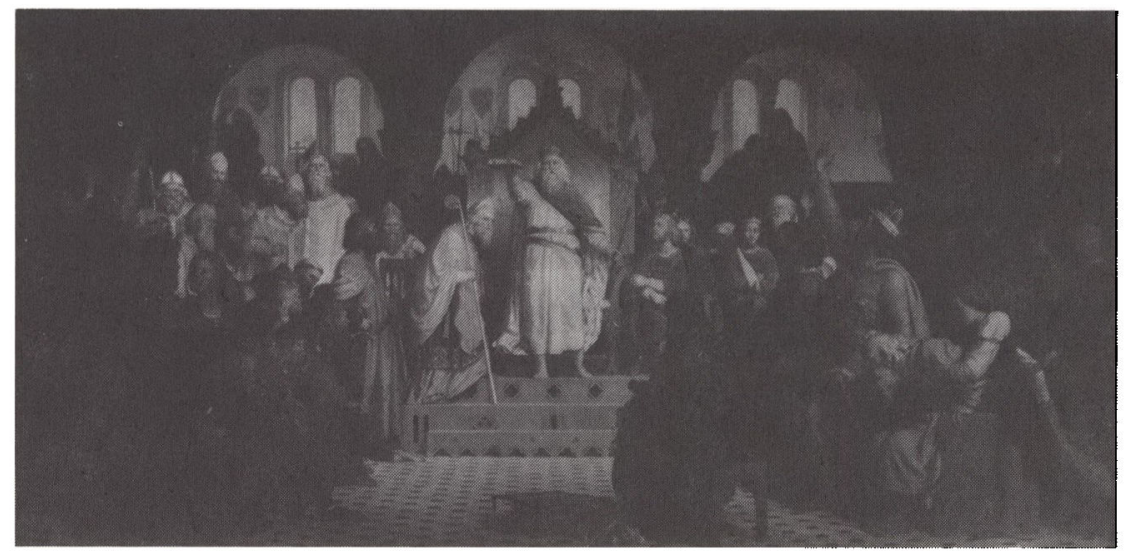

Et af de klassiske Frolichmalerier: Valdemar Sejr giver 1240 Jyske Lov. Billedet var sammen med et maleri af Frederik 4., der hyldes af standerne på Gottorp 1721, malet til appellationsretten $i$ Flensborg. Det blev 1882 flyttet til det nye domhus $i$ byen, hvor det stadig hanger. (Foto: Gerd Remmer)

mytologiske billeder, satte ministeriet i maj 1853 kunstneren stolen for døren, idet man over for Winstrup i utilslørede vendinger pegede på, at udførelsen af maleriet måske skulle overdrages en anden kunstner eller helt opgives. ${ }^{6}$ Resultatet blev, at Frølich to måneder senere afsendte 5 skitser, nemlig foruden de to, der var ønsket af ministeren, to mytologisk inspirerede (»Asernes guldalder« og »Lokes straf») samt »Dronning Thyra ved bygningen af Danevirke«. Inden Winstrup afleverede dem til ministeriet, blev de fremlagt $i$ en sal i Flensborgs rådhus "for at alle gode venner (i al hemmelighed) kunne glæde sig derover ${ }^{7}{ }^{7}$

I februar 1854 fulgte så ministeriets approbation - naturligvis af de to skitser, der dækkede Moltkes vilje - og derefter affattelsen af en kontrakt, der fastsatte honorar og leveringstid. Et par måneder senere var Frølich flyttet til Flensborg for at gå i gang med opgaven på stedet.

Med arbejdet under kontrol og med vished for subsidier fra de velstående forældre i København kunne Frølich nu tænke på at stifte hjem og familie, og i september 1855 holdt han i Paris bryllup med sin forlovede, Lina in de Bertou, en musikalsk begavet pige af svensk officersfamilie. Et fingerpeg om, hvor parret skulle flytte ind, får vi i et brev fra Frølich, hvor han fortæller, at hans vej hver dag går vfra 
appellationsretten til hans hjem bag byen over bakkerne«. Der var tale om en lejlighed i Sønder Hulvej, ikke langt fra Havretorvet. Her fødtes året efter deres første barn, datteren Elva. Dåben fandt sted i hjemmet med bl.a. Winstrup, fru Louise Muus og amtmand F. H. Wolfhagen som faddere. ${ }^{8}$

Alt imens havde der meldt sig visse vanskeligheder $\mathrm{i}$ forbindelse med det andet store billede til appellationsretten, det, der åbenbart interesserede kunstneren mindst. Han havde, som det er de fleste bekendt, valgt at portrættere en del kendte historiske personer i den figurgruppe, der omgiver kong Frederik 4. og var allerede gjort opmærksom på, at han ved at medtage Tordenskjold gjorde sig skyldig $i$ en klar anakronisme. Et par breve til Regenburg afspejler, at meningerne herom var delte. Regenburg (nu ministeriets departementschef) og politimester Garlieb havde udtrykt betænkeligheder, mens Wolfhagen, der netop overtog ministerposten efter C. C. Hall, fandt »at man ej behøvede at holde sig så strengt til historien «. ${ }^{9}$

Frølich havde altså en del problemer at slås med $\mathbf{i}$ »Parykstykket«, som Vilh. Kyhn kaldte det med fin forståelse for vennens forhold til denne del af opgaven; men i efteråret 1857, netop som lyset begyndte at aftage med årstiden, kunne han omsider lægge sidste hånd på værket, og da han samtidig følte sig stærkt forurettet, da en udsmykning af børssalen i København efter hans skitser blev bremset på halvvejen, besluttede han at forlade Flensborg og vende tilbage til Paris. ${ }^{10}$

Straks efter krigsudbruddet 1. februar 1864 fik Winstrup pålæg om at lade de to store malerier tage ned og fjerne fra Flensborg. Der kunne være tale om at sende dem enten til Als eller til København. Winstrup gik ind for det sidste, idet han tænkte sig dem udstillet på Charlottenborg, og havde netop fået dem anbragt på galleriet indpakket med transport for øje, da det uforudsete, pludselige tilbagetog fra Danevirke udelukkede enhver mulighed for at bringe billederne i sikkerhed. ${ }^{11}$

De blev nu preussisk statsejendom og som sådan rangeret ind på linje med andre reminiscenser fra Sydslesvigs danske fortid. I rejsevejledninger o.lign. er der ofte henvist til dem, men da en del af dette materiale efterhånden er forældet, kan der være grund til kort at føre deres skæbne up to date.

Valdemar Sejr-billedet har ikke på noget tidspunkt forladt Flensborg. 1882 flyttede det med over i det nye domhus i Sønder Gravene, og her befinder det sig den dag i dag, nærmere bestemt i kriminalrettens sal. ${ }^{12}$ Hyldings-billedet fik derimod plads i regeringsbygningen i Slesvig - 
tæt ved det sted, som Frølich havde valgt som kulisse for det historiske optrin. Her hang det i overpræsidentens audienssal, og det siges, at overpræsident Køller lod lave en kopi i mindre format. ${ }^{13}$ I 1909 var det udlånt til mindeudstillingen for Frølich i København. 1966 blev det taget $\mathrm{i}$ forvaring af det tyske Landesamt für Denkmalpflege, og det hænger nu i den historiske Landeshalle på slottet i Kiel.

Tilbage står kun at fastslå, at skønt de to kæmpebilleder - hver på $5.30 \times 2.80 \mathrm{~m}$ - er markante frembringelser inden for det 19 . århundredes historiemaleri, betegner de ikke nogen toppræstation, heller ikke i Frølichs egen produktion. Sådan har han også selv vurderet det: »Jeg gjorde mit bedste, dog vil det næppe blive disse arbejder, der giver mit navn betydning. ${ }^{14}$ De har krævet meget med hensyn til studier af dragter, portrætter m.v., men de har ikke udløst hans fulde skaberglæde. Den fik, som vi nu skal se, afløb i en række andre arbejder.

Her er det rimeligt først at omtale en bestilling, som satte Frølich i stand til at udføre en dekorationsopgave »helt efter sit eget sind«, hvilket vil sige med frit motivvalg. Den kom fra en landsmand, som siden 1848 var bosiddende i Flensborg, justitsråd, cand.pharm. Chr. M. Poulsen, der var repræsentant for det engelske jernbanefirma Peto, Brassey \& Betts. ${ }^{15}$ Poulsen lod 1856 - efter tegning af M. G. Bindesbøll - opføre en villa på en attraktiv grund ved Bov landevej, og Frølich fik til opgave at udsmykke havesalen med et maleri på hver af endevæggene. Han valgte $\mathrm{i}$ et halvcirkelformat på $2.92 \times 2 \mathrm{~m}$ at fremstille "Balders død « og »Thor kører ud på sin rejse til Jotunheim«.

Justitsråden så sig i 1864 tvunget til at forlade Flensborg, og villaen gik over på tyske hænder. Det førte til en gennemgribende forandring indendørs, og senere ejere ønskede at skille sig af med malerierne. Det er baggrunden for, at de kom med på mindeudstillingen for Frølich $\mathrm{i}$ 1909. ${ }^{16}$ Her købte malerens mangeårige nære ven, xylograf $F$. Hendriksen dem for at sikre, de kom i dansk eje. En passende anbringelse af billederne blev fundet, da arkitekt H. Lønborg-Jensen 1932-34 var i gang med ombygningen af Snoghøj Gymnastikhøjskole. Da det her kom på tale at søge en form for udsmykning tilvejebragt, blev der henvist til de to malerier, og med støtte fra Ny Carlsbergfonden blev de erhvervet til højskolen, hvor de siden har haft plads i hall'en. ${ }^{17}$

Da Frølich forud for brylluppet skulle indrette sit nye hjem, forsynede han det med møbler, han selv havde givet tegning til og selv dekoreret med bistand af landskabsmaleren C. A. Kølle, der også fungerede som medhjælper ved de store malerier. Det drejede sig om en stor seng, 

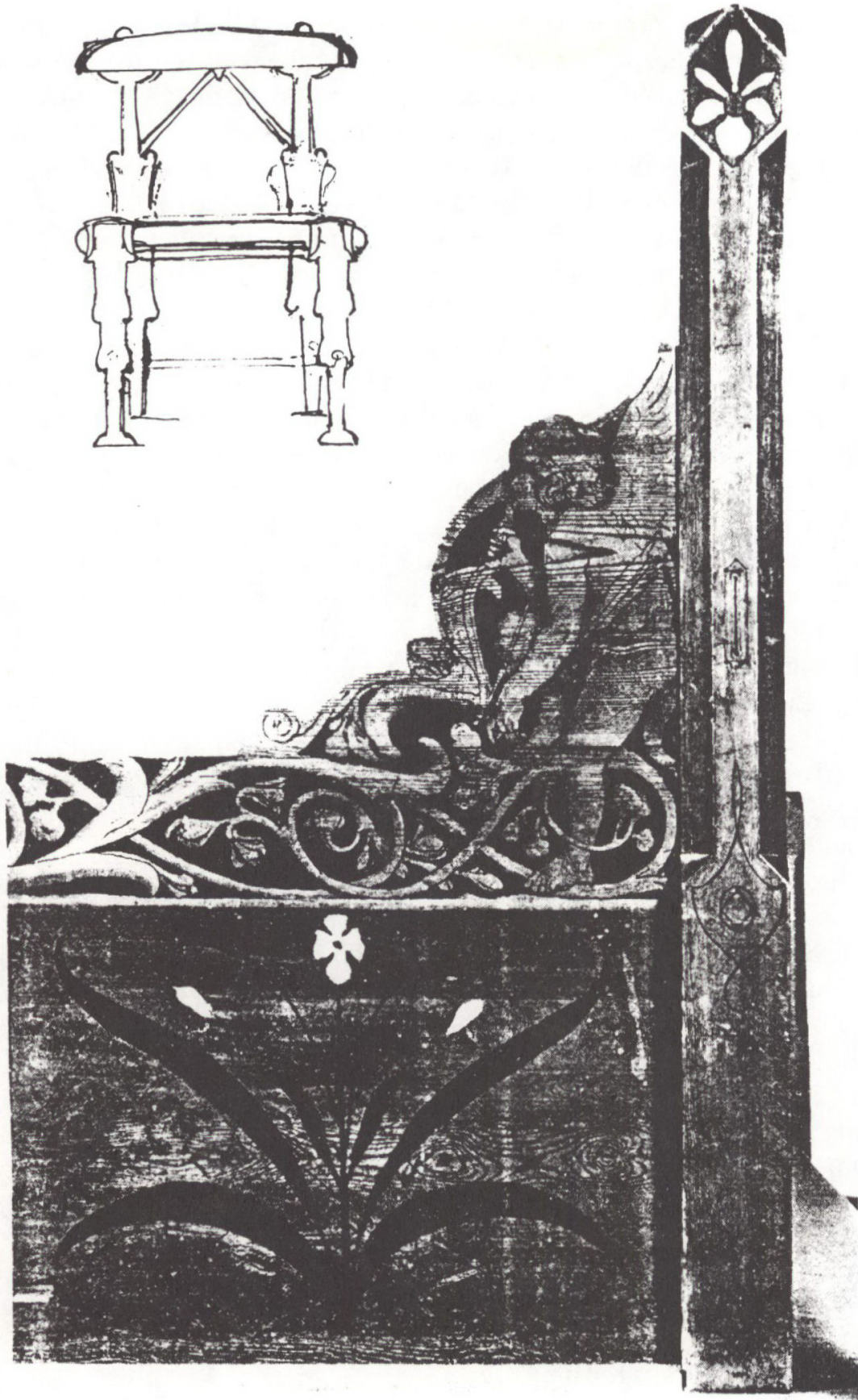

Lorenz Frolich som kunsthändvarker. Overst ses tegning til en stol, nederst hovedgardet til en seng, nu på Kunstindustrimuseet. 
et par stole, en sovesofa og en elmetræs servante. Sengen var udført af bejdset fyrretræ, der var grundpoleret og derpå afslebet og dekoreret med pensel. Den havde affasede hjørnestolper og lukket bund med 3 skuffer til sengetøj. Hovedgærde og fodgærde havde henholdsvis "Natten« og "Dagen« som allegoriske figurer, og også siderne var dekoreret: liljer og valmuer forbundet med spinkle ranker og ornamenter.

Ved opbruddet fra Flensborg blev møblementet splittet, idet noget af det blev solgt ved auktion. Størstedelen af det særprægede bohave er dog senere på ny blevet samlet hos familien, der atter har overladt det mest værdifulde til Kunstindustrimuseet i København. ${ }^{18}$

Vi vender os nu til et par eksempler på, at også kristeligt-religiøse motiver kunne udfordre malerens billedskabende talent.

Det er et forlæg af ham, dateret til 1854, der er bevaret i et dåbsfad, som kendes i 4 eksemplarer, alle fra Casper Møllers galvanoplastiske værksted. Det fornemste er nok det, der fik plads i slotskapellet på Gottorp, da det i april 1857 blev indviet som kirke for den danske menighed. ${ }^{19}$ De 3 andre fade tilhører kirkerne i Tårnby, Værløse og Herlev. Da disse lå under Københavns universitet, har man sikkert med rette tillagt professor $\mathrm{H}$. N. Clausen en vis indflydelse på udformningen, eksempelvis med hensyn til symbolik o.lign. ${ }^{20}$

Et større maleri, forestillende Kristi fristelse, kom med på en udstilling, som kunstforeningen i Flensborg afholdt i regeringsbygningen. Da det ikke var blevet solgt, blev det hængende i huset, da Frølich i 1857 forlod Flensborg. Det kom derved til at dele skæbne med de to store lærreder fra appellationsretten og blev, skønt det vitterligt var malerens privateje, beslaglagt af de preussiske myndigheder. Senere kom billedet med til det nye domhus, hvor det i dag hænger i nævningerettens sal, vis-á-vis anklagebænken. ${ }^{21}$

Man har ment, at maleriet var tiltænkt Husby kirke som altertavle. For antagelsens rigtighed taler dels formatet, dels den omstændighed, at bemeldte kirke netop gennemgik en restaurering i årene 1856-1859 under ledelse af L. A. Winstrup. ${ }^{22}$

Netop det år, Frølich tog ophold i Flensborg, skulle byen være ramme om arrangementer, der tjente til at understrege dens nye rang som Sønderjyllands hovedstad. Det gav den unge maler anledning til at bevæge sig lidt bort fra sit egentlige ambitionsniveau og slappe af med lidt »hakkelse i døgnets rejsestald«.

I ugen før pinse holdtes den store landmandsforsamling med deltagelse af mange udenbys gæster, såvel fra oplandet som fra kongeriget. 


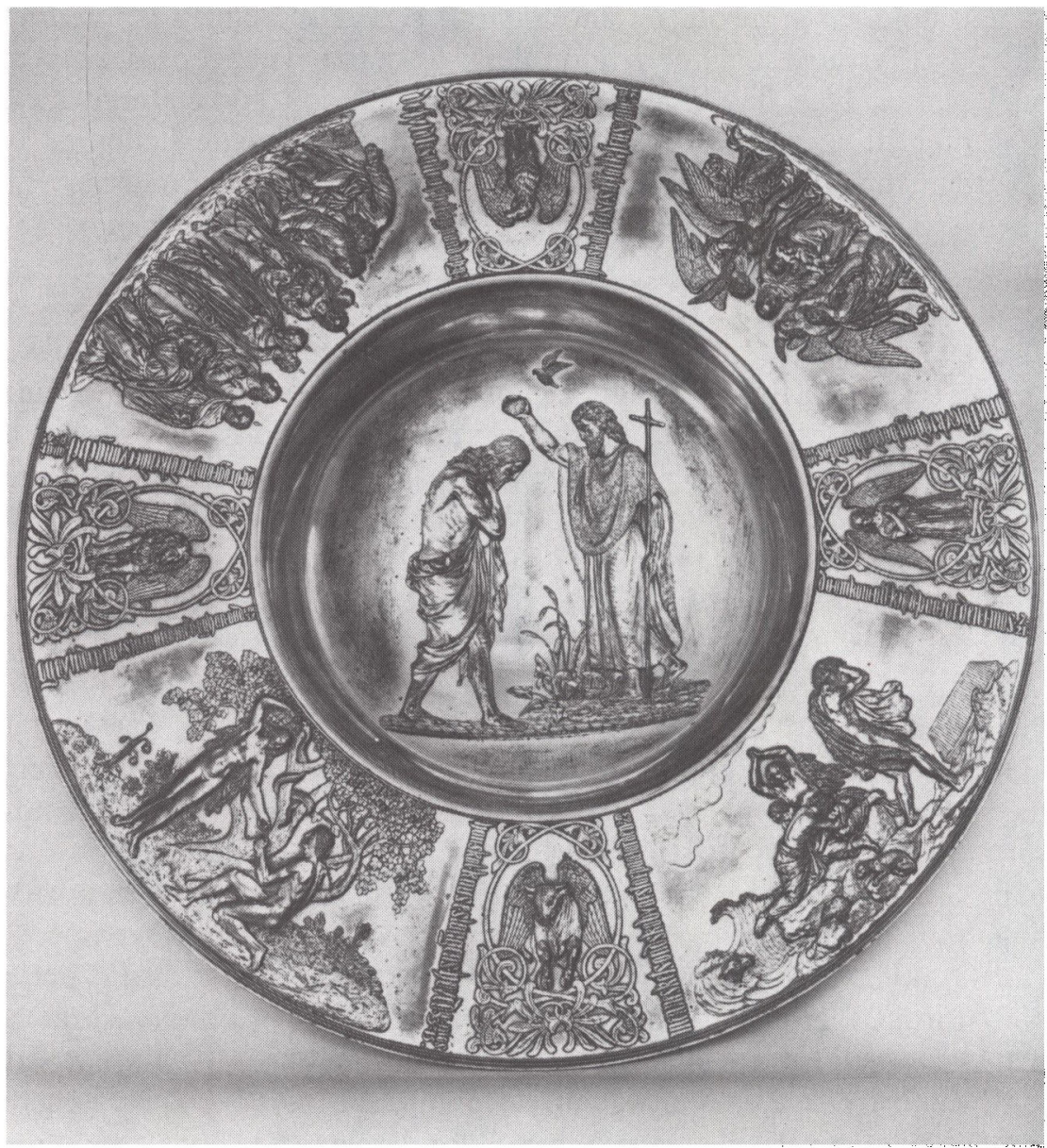

Dåbsfad til slotskapellet på Gottorp, efter forlag fra Lorenz Frølich. (Schleswig-Holsteinisches Landesmuseum)

Frølich har åbenbart besøgt dyrskuet med sin skitsebog, for blandt de 12 litograferede bilag til den trykte beretning bærer de to signaturen: L. Frølich del(ineavit). ${ }^{23} \mathrm{Og}$ da kongeparret $\mathrm{i}$ oktober samme år kom på officielt besøg, kunne han yde et kærkomment bidrag til de obligate festdekorationer. I et brev til Chr. F. Molbech fortæller han d. 20. oktober, at han har travlt med lejlighedsfigurer og transparenter, og $i$ en avisreportage nogle dage senere får vi at vide, hvad der var præsteret: 
"Størst var trængslen af nysgerrige ved rådhuset, hvor man under en transparent med det kongelige monogram så 5 store allegoriske billeder indrammet af en lang række lamper. Kvindefiguren i midten, som støtter sig til byvåbnet, er en personificering af byen Flensborg, der bringer kongen sin tak for de mange gaver, han har skænket byen, og som er fremstillet $i$ sidefigurerne. Ved den ene side er freden fremstillet $i$ en kvindeskikkelse, der svæver ud over et frugtbart land, og på modsat side svæver retfærdighedens gudinde over Flensborg, idet hun hentyder til, at appellationsretten er flyttet hertil. De to yderste figurer er sindbilleder på den handel og industri, der blomstrer i vor by ... Den fortrinlige udførelse af disse malerier skyldes hr. Frølich, som forestår den kunstneriske udsmykning af den herværende regeringsbygning. $\ll^{24}$

Et cirkelrundt skjold, hvor guden Frejr er afbildet, hører til samme kategori og er vel endog forbundet med samme historiske situation. Det ligger nemlig nær at antage, at det er en rest af udsmykningen af Borgerforeningens sal ved det bal, der blev holdt med kongen som midtpunkt den 24 . oktober om aftenen. I øvrigt et velkendt billede, brugt som titelvignet i Dahl og Linvalds "Sønderjylland « og fremdeles som omslagsvignet i Dansk Skoleforenings årsberetninger.

Et senere lejlighedsarbejde, typisk i sin art, knytter i ganske særlig grad Frølichs navn til den foretagsomhed og opblomstring, som udfoldede sig i mellemkrigstidens Flensborg. Det er den sølvplade, som blev indmuret ved grundstensnedlæggelsen til Winstrups nye latinskolebygning den 24. august 1857. Den bar foroven en halvkredsformet tegning, som viser to kvindeskikkelser, Danmark og Håbets genius, omgivet af skolebørn og med Nikolaj kirketårn og skibenes master i baggrunden. Det er denne komposition, der med ornamentik og indskrift er omsat til et glasmaleri i Duborgskolens festsal. ${ }^{25}$

Bestillingsarbejder af den ene eller den anden art kunne dog ikke $i$ længden tilfredsstille Frølichs maleglæde eller mætte trangen til fortsatte studier i naturen. Herom vidner nogle lærreder i mindre format med motiver fra de steder, hvor land og by dengang mødtes. Der kendes mindst 4, nemlig »Bybillede fra Flensborg « (privateje), »Landskab ved Flensborg" (Statens Museum for Kunst), "Landskab med huse og børn « (Glyptoteket) og »Landskab fra Flensborg med bakker « (Statens Kunstmuseum). At den romantiske forestillingsverden fremdeles ud- 


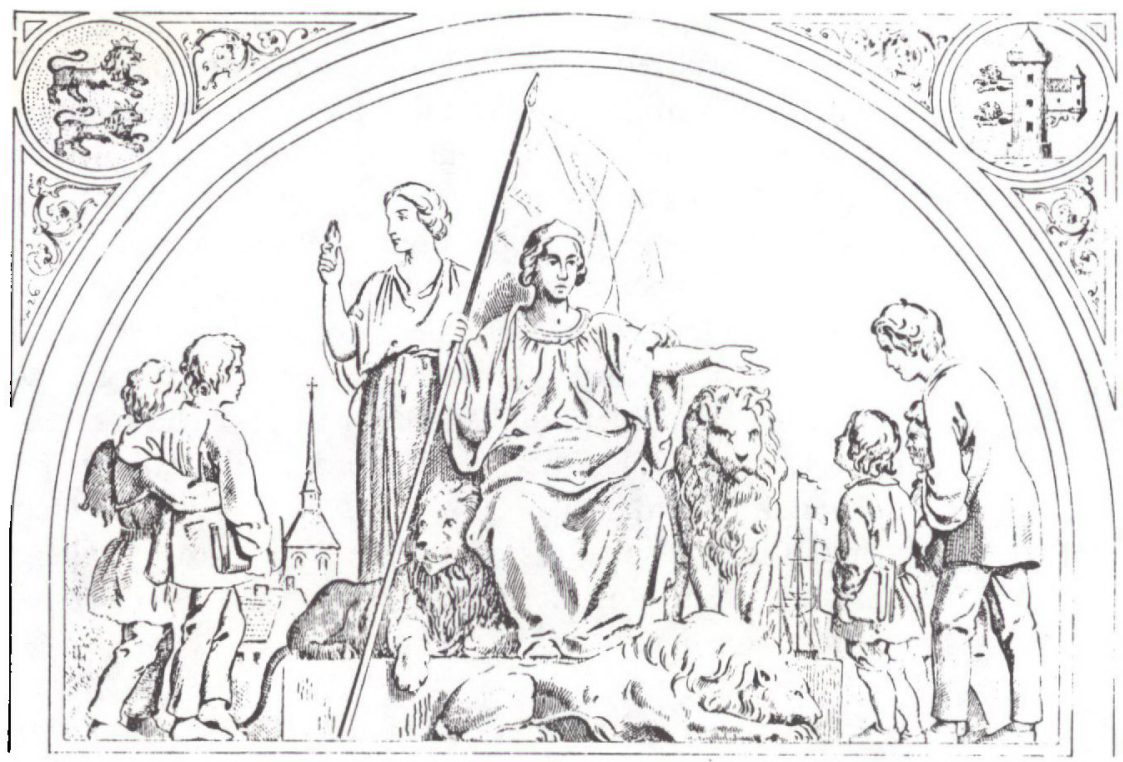

Tegning til grundstenspladen til Flensborg Latin- og realskole.

ovede sin tiltrækning, fremgår af skitsen »Niels Ebbesens hjemfærd «, hvor dog de maleriske problemer - modlyset f.eks. - helt har taget overhånd. Det udtryksfulde samspil mellem helten og kvinden, der skænker ham sit fattige brød, er langt heldigere udformet i de tegninger eller kemitypier, hvor han tidligere havde syslet med emnet. ${ }^{26}$

Allerede inden Frølichs død i 1908 havde man anlagt den vurdering, der ikke senere er blevet modsagt, at hans mesterskab som billedkunstner $i$ langt højere grad kom til udtryk $i$ hans grafiske arbejder end $i$ maleriet. Det er derfor naturligt til sidst at kaste et blik på en række tegninger, der med sikkerhed kan dateres til Flensborgtiden.

En delvis farvelagt pennetegning med motiv fra Saxo: Othar og Gyrithe (i den kgl. Kobberstiksamling) er forankret i den emnekreds han tidligt havde erklæret sin kærlighed: den nordiske mytologi. Fra hjemlivets tætte lilleverden, der netop her i Flensborg åbnede sig for ham, hentede han inspirationen til flere indtagende blyantstegninger af hustruen, Lina Frølich, og herfra kunne han atter slå over i en fint pointeret munterhed, som det ses i en tegning af de to hunde, der snakker de tobenede væsener efter munden: »Tror $d u$, Hector, Sebastopol kan holde sig? « 27 


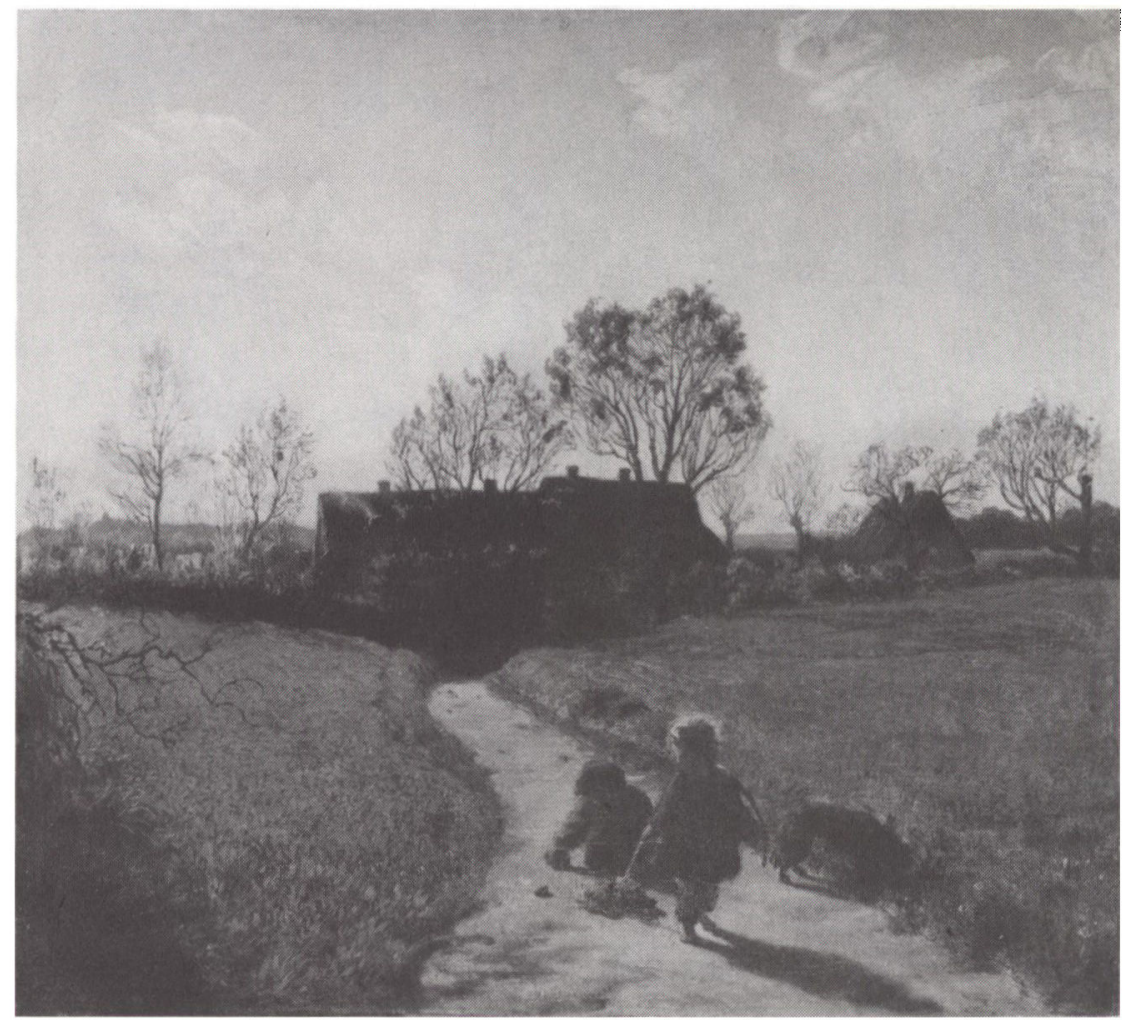

Landskabsmaleri fra Lorenz Frolichs Flensborgtid: Landskab med huse og born. (Glyptoteket)

Til disse eksempler slutter sig et antal bogillustrationer. De 6 litografier til Chr. Winthers "Hjortens flugt« tør vel regnes for et af de betydeligste arbejder fra hans unge år, mens et enkelt blad, skåret som træsnit af H. P. Hansen, i lange tider blev beundret for sin forening af fortættet klarhed og suggestiv kraft: Bønderne, der slæber sten til Kalø slot. Det fremkom sammen med en halv snes andre billeder i Danmarks illustrerede almanak for 1856. Folkekalender for Danmark $1857 \mathrm{og}$ M. Goldschmidts ugeskrift "Nord og Syd « samme år bragte yderligere forvarsler om hans formidable evne til at omsætte en fantasibetonet verden i plastisk skønne billeder, den evne, der med rette indbragte ham Georg Brandes' åndfulde hyldest til hans 80-årsdag: "Konge til fabelland, de heltes og guders, hertug til drømmeland, sagaland, alfeland og slaraffenland, herre over Olympen, Valhal, Asgård, Utgård, 


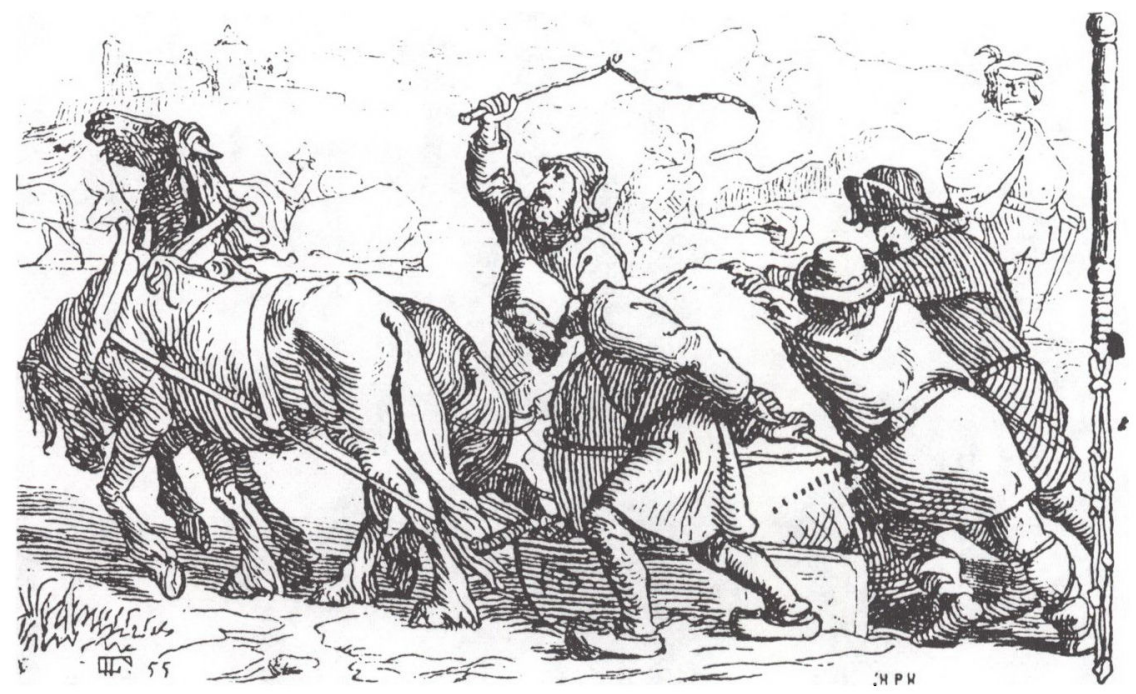

Lorenz Frolich som bogillustrator 1855. Tegning af bonderne, der slaber sten til bygningen af Kalo slot. (Danmarks illustrerede Almanak for 1856)

de jætters og troldes - dog aldrig for stor til at lade de små, børnene og dyrene, komme til sig. « $^{28}$

Vi har her kun beskæftiget os med et lille udsnit af det »rige«, som Lorenz Frølich efterhånden underlagde sig, og kunsthistoriske hegnspæle er derfor næppe blevet flyttet. Sigtet med dette bidrag har da også været et andet og mere beskedent: at efterprøve vor viden om et begrænset tidsafsnit og derigennem belyse en åndshistorisk virkelighed så væsensforskellig fra det billede, vore dages hårdtprøvede turiststrøm får med sig fra Flensborg.

\section{NOTER}

1. Arkitekten L. A. Winstrups vigtigste arbejder, Sjy Årb 1946, s. 120 ff.

2. Eksempelvis kan nævnes: Hanne Westergaard: L. F. Et bidrag til hans illustrationskunst (Bogvennen 1964), Th. Oppermann: L. F. i Flensborg (Sønderjysk julealbum 1919), Elise Konstantin-Hansen: Dansk malerkunst og L. F. (Dansk Udsyn årg. 15, 1935), Bernhard Hansen: L. F. i Flensborg (Holger Danske 1927, nr. 2 og 8, 
samt Duborg-Samfundets årsskrift 1943) og Kai Stage: L. F. og det gamle Blidah (Gentofte-bogen 1971). Endvidere Udstillingskataloger 1968 (Thorvaldsens Museum) og 1971 (Statens Museum for kunst) samt Aviskronikker: Berl. Aften 17.-18.10. 1970, Flensborg Avis 16.5. 1955 og 4.5. 1956.

3. Det var købmandsgården Holmen 19/21, der efter mange omskiftelser nu har givet plads for stormagasinet Hertie. Se bl.a. Kunsttopographie Schleswig-Holstein, 1974, og Flensburg in Geschichte und Gegenwart, 1972.

4. Winstrup til ministeriet 4.10. $1852 \mathrm{og}$ til Frølich 5.10. 1852. Når der her og i det følgende refereres til parternes korrespondance sker det på grundlag af Henny Glarbos offentliggørelse af Frølichs breve i Tilskueren 1930 og Lorenz Frølich. Egne optegnelser og breve, samlet og udgivet af F. Hendriksen, 1920-21.

5. Winstrup til Frølich 30.4. 1853.

6. Carl Moltke til Winstrup 18.5. 1853.

7. Frølich til Winstrup 11.7. 1853 og Winstrups svar 29.7. 1853.

8. Den lille datter døde i juli 1857. - Kirkebogen for Den danske Menighed i Flensborg.

9. Frølich til Regenburg 16.6. 1856. - K. W. Garlieb var politimester i Flensborg fra 1850 til sin død i 1858.

10. Vilh. Kyhn til Frølich 1856 (udateret). Frølich til Chr. K. F. Molbech 26.6. 1857.

11. Tilskueren 1930, s. 211.

12. Flensburger Nachrichten 11.10. 1982.

13. Doris Schnitger i Die Heimat 1909, s. 34.

14. Th. Oppermann i Sønderjysk julealbum 1919, s. 6.

15. Dansk skovforenings tidsskrift 1918 , s. 101f.

16. F. Hendriksen: Et landsted ved Flensborg. Architekten 20. årg. 1918, s. $361 \mathrm{f}$.

17. F. Hendriksen: Om Snoghøj billederne, i Snoghøjbogen 1933, s. 29ff. - Den oprindelige udskæring for dørfelterne er ved restaureringen blevet udfyldt og forsynet med en tekst fra Oehlenschlägers »Nordens guder» og "Baldur hiin gode«.

18. Erik Lassen: Frølichs møbler, i Kunstmuseets udstillingskatalog 1971, s. $14 \mathrm{ff}$.

19. Se feltpræsten E. Høyer-Møller's »Livs- og krigserindringer fra 1850-1864, s. $117 \mathrm{f}$. Bondo Svane bestrider dog (anf. arb. s. 212), at fadet var en gave fra danske officerer.

20. Danmarks kirker, udg. af Nationalmuseet, Københavns amt bd. 1. jfr. F. Hendriksen: L. F. Egne optegnelser og breve, s. 283.

21. Flensburger Nachrichten, anf. nr.

22. Trap Slesvig, II s. 482.

23. C. F. Linde: Beretning om den 5. danske landmandsforsamling i Flensborg 29/52/6 1854. Kbh. 1855 (pl. I: lysebrun hingst og pl. III: Broget marsktyr).

24. Flensburger Zeitung 25.10. og 27.10. 1854.

25. Skænket af grosserer J. C. Møller. Duborg-Samfundets årsskrift 1943, s. 30.

26. Afbildet bl.a. i Axel Olrik: Danske heltesagn, Kbh. 1900 og senere udgaver.

27. Under Krimkrigen strakte den langvarige belejring af fæstningen Sevastopol sig fra 9.10. 1854 til 11.9. 1855.

28. Cand.theol. \& mag. Marie Christensen i Fl Av 16.5. 1955. 
